\title{
The onset of clinical manifestations in inflammatory bowel disease patients
}

\author{
Viviane Gomes NÓBREGA' ${ }^{1}$ Isaac Neri de Novais SILVA' ${ }^{1}$, Beatriz Silva BRITO ${ }^{1}$, Juliana SILVA ${ }^{1}$, \\ Maria Carolina Martins da SILVA ${ }^{1}$ and Genoile Oliveira SANTANA ${ }^{2,3}$
}

Received 29/10/2017 Accepted 10/8/2018

\begin{abstract}
Background - The diagnosis of inflammatory bowel disease is often delayed because of the lack of an ability to recognize its major clinical manifestations. Objective-Our study aimed to describe the onset of clinical manifestations in inflammatory bowel disease patients. Methods - A cross-sectional study. Investigators obtained data from interviews and the medical records of inflammatory bowel disease patients from a reference centre located in Brazil. Results - A total of 306 patients were included. The mean time between onset of symptoms and diagnosis was 28 months for Crohn's disease and 19 months for ulcerative colitis. The main clinical manifestations in Crohn's disease patients were weight loss, abdominal pain, diarrhoea and asthenia. The most relevant symptoms in ulcerative colitis patients were blood in the stool, faecal urgency, diarrhoea, mucus in the stool, weight loss, abdominal pain and asthenia. It was observed that weight loss, abdominal pain and distension, asthenia, appetite loss, anaemia, insomnia, fever, nausea, perianal disease, extraintestinal manifestation, oral thrush, vomiting and abdominal mass were more frequent in Crohn's patients than in ulcerative colitis patients. The frequencies of urgency, faecal incontinence, faeces with mucus and blood, tenesmus and constipation were higher in ulcerative colitis patients than in Crohn's disease patients. The mean time from the onset of clinical symptoms to the diagnosis of Crohn's disease was 37 months for patients with ileocolonic location, 26 months for patients with ileum location and 18 months for patients with colon location. In ulcerative colitis patients, the mean time from the onset of symptoms to diagnosis was 52 months for proctitis, 12 months for left-sided colitis and 12 months for extensive colitis. Conclusion Ulcerative colitis presented a high frequency of intestinal symptoms, and Crohn's disease showed a high frequency of systemic manifestations at the onset of manifestation. There was a long delay in diagnosis, but individuals with more extensive disease and more obvious symptoms showed a shorter delay.
\end{abstract} HEADINGS - Inflammatory bowel diseases. Crohn disease. Ulcerative colitis.

\section{INTRODUCTION}

Inflammatory bowel disease (IBD) is characterized by chronic inflammation of the gastrointestinal tract that may present pleomorphic clinical manifestations. The most common forms are ulcerative colitis (UC) and Crohn's disease (CD) ${ }^{(1,2)}$.

$\mathrm{CD}$ may affect the entire digestive tract from the mouth to the perianal region; its inflammatory process is characterized by discontinuous and segmental injuries that affect all layers of the intestine (transmural inflammation) $)^{(3)}$. The location is closely related to the clinical manifestation ${ }^{(4,5)}$. The symptoms of CD are heterogeneous but generally include abdominal pain, weight loss and chronic diarrhoea ${ }^{(1,4,6)}$.

UC is characterized by diffuse inflammation of the colon restricted to the mucosa that usually affects the rectum and presents a proximal extension in a symmetrical and continuous pattern ${ }^{(1,3,7)}$. Symptoms depend on the extent and severity of the disease and more commonly include bloody diarrhoea, rectal bleeding and/or rectal urgency, but these patients also describe faecal incontinence, tenesmus and abdominal pain. Systemic symptoms of malaise, anorexia, fever or even nausea and vomiting may be present mainly during a severe $\operatorname{attack}^{(6-9)}$.
IBD can lead to disability and can have a significant impact on quality of life, with significant mental health problems, including depression. Moreover, patients develop professional and social constraints that interfere with work and recreational activities and result in decreased sexual satisfaction compared to the general population $^{(6,10-12)}$.

The incidence of IBD is highest in the United States, the United Kingdom and Scandinavia ${ }^{(13)}$. Moreover, studies from IBD centres in Brazil report a clear increase in the prevalence of IBD in recent years ${ }^{(14,15)}$. Despite this rise, IBD is still a relatively unknown disease, and its diagnosis is often delayed ${ }^{(13)}$. Our study aimed to describe the onset of clinical manifestations presented by these patients.

\section{METHODS}

This was a cross-sectional and observational study. The data were collected in the reference centre for inflammatory bowel disease at Hospital Geral Roberto Santos, Bahia, Brazil. The study was conducted between April 2015 and July 2016. The sample included patients from the outpatient unit. This study included consecutive IBD patients ( $\geq 18$ year of age). Patients were interviewed about clinical manifestations. Information about the Montreal classification was

Declared conflict of interest of all authors: none

Disclosure of funding: no funding received

${ }^{1}$ Universidade do Estado da Bahia, Salvador, BA, Brasil. ${ }^{2}$ Universidade do Estado da Bahia, Departamento de Ciências da Vida, Salvador, BA, Brasil. ${ }^{3}$ Universidade Federal da Bahia,

Programa de Pós-Graduação em Medicina e Saúde, Salvador, BA, Brasil.

Research performed at: Hospital Geral Roberto Santos, Centro de Referência para Doença Inflamatória Intestinal, Salvador, BA, Brasil.

Corresponding author: Genoile Oliveira Santana. Orcid: 0000-0001-5936-9791. E-mail: genoile@uol.com.br 
collected from medical records. The following variables were included in the study: sex, age at diagnosis, age at onset of the symptoms, time from symptoms to diagnosis, the Montreal classification, nausea, vomiting, abdominal pain, diarrhoea, incontinence, faecal urgency, tenesmus, abdominal distension, the presence of blood and mucus in the stool, weight loss, appetite loss, constipation, malnutrition, anaemia, fever, asthenia, insomnia, abdominal mass, mouth ulcers, perianal disease and extraintestinal diseases. The study was approved by the institutional ethics committee. Informed written consent was obtained from each patient. Data were analysed with the Statistical Package for Social Sciences (version 21.0, SPSS, Chicago, IL).

\section{RESULTS}

This study included 306 patients. Epidemiological data are presented in TABLE 1. Occasionally, patients received a diagnosis before clinical manifestation.

TABLE 1. Epidemiological and clinical characteristics of inflammatory bowel disease patients $(n=306)$.

\begin{tabular}{lcc}
\hline Characteristics & $\begin{array}{c}\text { Crohn's disease } \\
(\mathrm{n}=141)\end{array}$ & $\begin{array}{c}\text { Ulcerative colitis } \\
(\mathrm{n}=165)\end{array}$ \\
\hline Sex n $(\%)$ & $89(63.1 \%)$ & $102(61.1 \%)$ \\
$\quad$ Female & $52(36.9 \%)$ & $65(38.9 \%)$ \\
$\quad$ Male & $36( \pm 14)$ & $38( \pm 12)$ \\
Age at diagnosis (in years) & $13-78$ & $16-78$ \\
$\quad$ Mean & & \\
Range & $33( \pm 14)$ & $36( \pm 12)$ \\
Age at onset of symptoms (in years) & $3-77$ \\
Mean & $9-78$ & $19( \pm 46)$ \\
$\quad$ Range & $28( \pm 48)$ & \\
Time to diagnosis (in months) & & \\
\hline
\end{tabular}

The patients were classified according to the Montreal classification, but 21 (6.7\%) IBD patients could not be classified (TABLE 2).

The mean time from the onset of clinical symptoms to the diagnosis of CD was 37 months for patients with ileocolonic location, 26 months for patients with ileum location and 18 months for patients with colon location. In UC patients, the mean time from the onset of symptoms to diagnosis was 52 months for proctitis, 12 months for left-sided colitis and 12 months for extensive colitis.

TABLE 3 shows the frequency of each one of the clinical manifestations for all patients.

TABLE 4 presents the onset of clinical manifestations according to the location for $\mathrm{CD}$ patients.

TABLE 5 presents the onset of clinical manifestations according to the age at diagnosis for CD patients.

TABLE 6 presents the onset of clinical manifestations for UC patients according to the extent of disease.

\section{DISCUSSION}

IBD remains a poorly understood disease. This lack of knowledge has caused delays in IBD diagnosis. Furthermore, there are few studies regarding the onset of clinical manifestations of IBD. Our study contributes as a pioneering evaluation of this subject in Brazil.
TABLE 2. Montreal classification of inflammatory bowel disease patients $(\mathrm{n}=285)$.

\begin{tabular}{lc}
\hline Crohn's disease & $\mathbf{n}(\%)$ \\
\hline Age at diagnosis (A) & $11(7.9 \%)$ \\
A1 <16 years & $83(59.7 \%)$ \\
A2 17-40 years & $44(31.7 \%)$ \\
A3 > 40 years & \\
Location (L) & $25(18.7 \%)$ \\
Ileum (L1) & $55(41.0 \%)$ \\
Colon (L2) & $49(36.6 \%)$ \\
Ileocolon (L3) & - \\
Isolated upper digestive (L4) & $1(0.7 \%)$ \\
L4 + L1 & $1(0.7 \%)$ \\
L4 + L2 & $3(2.2 \%)$ \\
L4 + L3 & \\
Behaviour (B) & $54(39.7 \%)$ \\
No stricturing/no penetrating (B1) & $17(12.5 \%)$ \\
Stricturing (B2) & $11(8.1 \%)$ \\
Penetrating (B3) & \\
Perianal disease (p) & $24(17.6 \%)$ \\
B1 + p & $12(8.8 \%)$ \\
B2 + p & $18(13.2 \%)$ \\
B3 + p & \\
Ulcerative colitis & \\
Extension & $27(17.9 \%)$ \\
Proctitis (E1) & $67(44.4 \%)$ \\
Left-sided colitis (E2) & $57(37.7 \%)$ \\
Extensive colitis (E3) &
\end{tabular}

TABLE 3. The onset of clinical manifestations in inflammatory bowel disease patients $(n=306)$.

\begin{tabular}{lccc}
\hline Clinical & $\begin{array}{c}\mathrm{CD}(\mathrm{n}=141) \\
\mathrm{n}(\%)\end{array}$ & $\begin{array}{c}\mathrm{UC}(\mathrm{n}=165) \\
\mathrm{n}(\%)\end{array}$ & $\begin{array}{c}\text { IBD }(\mathrm{n}=306) \\
\mathbf{n}(\%)\end{array}$ \\
\hline Weight loss & $127(90 \%)$ & $128(76.6 \%)$ & $255(82.8 \%)$ \\
Abdominal pain & $119(84.4 \%)$ & $121(72.5 \%)$ & $240(78 \%)$ \\
Diarrhoea & $113(80 \%)$ & $133(79.6 \%)$ & $246(80 \%)$ \\
Asthenia & $113(80 \%)$ & $118(70.7 \%)$ & $231(75 \%)$ \\
Faecal urgency & $104(74 \%)$ & $139(83.2 \%)$ & $243(79 \%)$ \\
Appetite loss & $97(68.8 \%)$ & $86(51.5 \%)$ & $183(59.4 \%)$ \\
Malnutrition & $94(66.7 \%)$ & $51(30.5 \%)$ & $145(47 \%)$ \\
Anaemia & $88(62.4 \%)$ & $74(44.3 \%)$ & $162(52.6 \%)$ \\
Mucus in the stool & $85(60.3 \%)$ & $129(77 \%)$ & $214(70 \%)$ \\
Blood in the stool & $78(55.3 \%)$ & $141(84.4 \%)$ & $219(71 \%)$ \\
Tenesmus & $78(55.3 \%)$ & $104(62.3 \%)$ & $182(59 \%)$ \\
Abdominal distension & $73(54 \%)$ & $78(46.7 \%)$ & $154(50 \%)$ \\
Insomnia & $73(51.2 \%)$ & $69(41.3 \%)$ & $142(46 \%)$ \\
Faecal incontinence & $70(49.6 \%)$ & $104(62.3 \%)$ & $174(56.5 \%)$ \\
Fever & $66(46.8 \%)$ & $52(31 \%)$ & $118(38.3 \%)$ \\
Nausea & $64(45.4 \%)$ & $52(31 \%)$ & $116(37.7 \%)$ \\
Perianal disease & $62(44 \%)$ & $7(4.2 \%)$ & $69(22.4 \%)$ \\
Extraintestinal diseases & $60(42.6 \%)$ & $68(40.7 \%)$ & $128(41.6 \%)$ \\
Mouth ulcers & $55(39 \%)$ & $28(16.3 \%)$ & $83(27 \%)$ \\
Vomiting & $47(33.3 \%)$ & $31(18.6 \%)$ & $78(25.3 \%)$ \\
Abdominal mass & $23(16.3 \%)$ & $11(6.6 \%)$ & $34(11 \%)$ \\
Constipation & $13(9.2 \%)$ & $20(12 \%)$ & $33(10.7 \%)$ \\
\hline & & &
\end{tabular}


TABLE 4 . The onset of clinical manifestations according to the Montreal classification for location in Crohn's disease patients ( $\mathrm{n}=134)$.

\begin{tabular}{lccc}
\hline $\begin{array}{l}\text { Clinical } \\
\text { manifestations }\end{array}$ & $\begin{array}{c}\text { Ileum }(\mathbf{n}=26) \\
\mathbf{n}(\%)\end{array}$ & $\begin{array}{c}\text { Colon }(\mathbf{n}=56) \\
\mathbf{n}(\%)\end{array}$ & $\begin{array}{c}\text { Ileocolon }(\mathbf{n}=52) \\
\mathbf{n}(\%)\end{array}$ \\
\hline Weight loss & $22(84.6 \%)$ & $53(94.6 \%)$ & $46(88.5 \%)$ \\
Abdominal pain & $22(84.6 \%)$ & $49(87.5 \%)$ & $42(80.8 \%)$ \\
Diarrhoea & $22(84.6 \%)$ & $52(96.3 \%)$ & $38(74.5 \%)$ \\
Asthenia & $23(88.5 \%)$ & $48(85.7 \%)$ & $35(67.3 \%)$ \\
Faecal urgency & $15(57.7 \%)$ & $46(82.1 \%)$ & $37(71.2 \%)$ \\
Appetite loss & $18(69.2 \%)$ & $44(64.3 \%)$ & $29(55.8 \%)$ \\
Malnutrition & $15(57.7 \%)$ & $39(69.6 \%)$ & $34(65.4 \%)$ \\
Anaemia & $17(65.4 \%)$ & $38(67.9 \%)$ & $27(51.9 \%)$ \\
Mucus in the stool & $16(61.5 \%)$ & $36(64.3 \%)$ & $28(53.8 \%)$ \\
Blood in the stool & $08(30.8 \%)$ & $38(67.9 \%)$ & $29(55.8 \%)$ \\
Tenesmus & $114(2.3 \%)$ & $36(64.3 \%)$ & $26(50 \%)$ \\
Abdominal & $16(61.5 \%)$ & $23(41.1 \%)$ & $30(57.7 \%)$ \\
distension & $12(46.2 \%)$ & $30(53.6 \%)$ & $28(53.8 \%)$ \\
Insomnia & $07(26.9 \%)$ & $34(60.7 \%)$ & $27(51.9 \%)$ \\
Faecal & $11(42.3 \%)$ & $27(48.2 \%)$ & $22(42.3 \%)$ \\
incontinence & $15(57.7 \%)$ & $26(46.4 \%)$ & $19(36.5 \%)$ \\
Fever & $10(38.5 \%)$ & $25(44.6 \%)$ & $21(40.4 \%)$ \\
Nausea & $14(53.8 \%)$ & $22(39.3 \%)$ & $19(36.5 \%)$ \\
Perianal disease & $11(42.3 \%)$ & $24(42.9 \%)$ & $17(32.7 \%)$ \\
Extraintestinal & $10(38.5 \%)$ & $21(37.5 \%)$ & $12(23 \%)$ \\
diseases & $03(11.5 \%)$ & $06(10.7 \%)$ & $12(23.1 \%)$ \\
Mouth ulcers & $02(7.7 \%)$ & $03(5.4 \%)$ & $03(5.8 \%)$ \\
Vomiting & & & \\
Abdominal mass & & & \\
Constipation & & &
\end{tabular}

TABLE 5. The onset of clinical manifestations according to the Montreal classification for age at diagnosis of Crohn's disease patients $(\mathrm{n}=134)$.

\begin{tabular}{|c|c|c|c|}
\hline $\begin{array}{l}\text { Clinical } \\
\text { manifestations }\end{array}$ & $\begin{array}{c}<16 \mathrm{yr}(\mathrm{n}=11) \\
\mathrm{n}(\%)\end{array}$ & $\begin{array}{c}17 \text { to } 40 \mathrm{yr}(\mathrm{n}=80) \\
\mathrm{n}(\%)\end{array}$ & $\begin{array}{c}>40 \mathrm{yr}(\mathrm{n}=43) \\
\mathrm{n}(\%)\end{array}$ \\
\hline Weight loss & $11(100 \%)$ & $78(94 \%)$ & $35(80 \%)$ \\
\hline Abdominal pain & $10(91 \%)$ & $69(83 \%)$ & $37(84 \%)$ \\
\hline Diarrhoea & $09(81.8 \%)$ & $69(83 \%)$ & $34(77.3 \%)$ \\
\hline Asthenia & $09(81.8 \%)$ & $70(84.3 \%)$ & $31(70.5 \%)$ \\
\hline Faecal urgency & $09(81.8 \%)$ & $60(73.3 \%)$ & $32(72.7 \%)$ \\
\hline Appetite loss & $07(63.6 \%)$ & $59(71 \%)$ & $29(66 \%)$ \\
\hline Malnutrition & $09(81.8 \%)$ & $56(67.5 \%)$ & $27(61.4 \%)$ \\
\hline Anaemia & $10(91 \%)$ & $54(65 \%)$ & $21(47.7 \%)$ \\
\hline $\begin{array}{l}\text { Mucus in the } \\
\text { stool }\end{array}$ & $06(54.5 \%)$ & $54(65 \%)$ & $23(52.3 \%)$ \\
\hline $\begin{array}{l}\text { Blood in the } \\
\text { stool }\end{array}$ & $09(81.8 \%)$ & $47(56.6 \%)$ & $20(45.5 \%)$ \\
\hline Tenesmus & $08(72.7 \%)$ & $47(56.6 \%)$ & $21(47.7 \%)$ \\
\hline $\begin{array}{l}\text { Abdominal } \\
\text { distension }\end{array}$ & $04(36.4 \%)$ & $44(53 \%)$ & $25(56.8 \%)$ \\
\hline Insomnia & $04(36.4 \%)$ & $40(48.2 \%)$ & $28(63.6 \%)$ \\
\hline $\begin{array}{l}\text { Faecal } \\
\text { incontinence }\end{array}$ & $08(72.7 \%)$ & $39(47 \%)$ & $23(53.3 \%)$ \\
\hline Fever & $05(45.5 \%)$ & $38(45.8 \%)$ & $20(45.5 \%)$ \\
\hline Nausea & $07(63.6 \%)$ & $41(50 \%)$ & $14(31.8 \%)$ \\
\hline Perianal disease & $05(45.5 \%)$ & $41(50 \%)$ & $14(31.8 \%)$ \\
\hline $\begin{array}{l}\text { Extraintestinal } \\
\text { diseases }\end{array}$ & $06(54.4 \%)$ & $33(40 \%)$ & $19(43 \%)$ \\
\hline Mouth ulcers & $07(63.6 \%)$ & $35(42,2 \%)$ & $11(25 \%)$ \\
\hline Vomiting & $05(45.5 \%)$ & $28(33.7 \%)$ & $12(27.3 \%)$ \\
\hline $\begin{array}{l}\text { Abdominal } \\
\text { mass }\end{array}$ & $02(18.2 \%)$ & $14(17 \%)$ & $06(13.6 \%)$ \\
\hline Constipation & $02(18.2 \%)$ & $06(7.2 \%)$ & $03(6.8 \%)$ \\
\hline
\end{tabular}

TABLE 6 . The onset of clinical manifestations according to the Montreal classification of ulcerative colitis patients $(n=151)$.

\begin{tabular}{lccc}
\hline $\begin{array}{l}\text { Clinical } \\
\text { manifestations }\end{array}$ & $\begin{array}{c}\text { Proctitis } \\
(\mathbf{n = 2 7 )} \\
\mathbf{n}(\%)\end{array}$ & $\begin{array}{c}\text { Left-sided } \\
\text { colitis }(\mathbf{n}=67) \\
\mathbf{n}(\%)\end{array}$ & $\begin{array}{c}\text { Extensive } \\
\text { colitis }(\mathbf{n}=57) \\
\mathbf{n}(\%)\end{array}$ \\
\hline Blood in the stool & $22(81.5 \%)$ & $59(88 \%)$ & $48(84.2 \%)$ \\
Faecal urgency & $18(66.7 \%)$ & $59(88 \%)$ & $50(87.7 \%)$ \\
Diarrhoea & $19(70.4 \%)$ & $62(92.5 \%)$ & $52(91.2 \%)$ \\
Mucus in the stool & $19(70.4 \%)$ & $55(82 \%)$ & $42(73.3 \%)$ \\
Weight loss & $17(63 \%)$ & $53(79 \%)$ & $47(82.5 \%)$ \\
Abdominal pain & $19(70.4 \%)$ & $50(74.6 \%)$ & $42(73.7 \%)$ \\
Asthenia & $14(52 \%)$ & $47(70 \%)$ & $48(84.2 \%)$ \\
Tenesmus & $17(63 \%)$ & $47(70 \%)$ & $32(56 \%)$ \\
Faecal incontinence & $15(55.6 \%)$ & $47(70 \%)$ & $34(59.6 \%)$ \\
Appetite loss & $16(59.3 \%)$ & $33(49.3 \%)$ & $29(51 \%)$ \\
Abdominal distension & $12(44.4 \%)$ & $36(53.7 \%)$ & $24(42 \%)$ \\
Anaemia & $06(22.2 \%)$ & $33(49.3 \%)$ & $29(51 \%)$ \\
Insomnia & $10(37 \%)$ & $28(42 \%)$ & $24(42 \%)$ \\
Fever & $09(33.3 \%)$ & $18(27 \%)$ & $22(38.6 \%)$ \\
Nausea & $08(27 \%)$ & $23(34.3 \%)$ & $19(33.3 \%)$ \\
Malnutrition & $06(22.2 \%)$ & $17(25.4 \%)$ & $23(40.4 \%)$ \\
Extraintestinal diseases & $08(29.6 \%)$ & $26(38.8 \%)$ & $28(49 \%)$ \\
Vomiting & $05(18,5 \%)$ & $13(19.4 \%)$ & $12(21 \%)$ \\
Mouth ulcers & $03(11 \%)$ & $12(18 \%)$ & $11(19.3 \%)$ \\
Constipation & $04(14.8 \%)$ & $02(3 \%)$ & $03(5.3 \%)$ \\
Abdominal mass & $02(7.4 \%)$ & $06(9 \%)$ & $03(5.3 \%)$ \\
Perianal disease & $0 \% \%$ & $03(4.5 \%)$ & $01(1.8 \%)$ \\
\hline
\end{tabular}

The majority of patients in our study had UC (54\%), following the trend of other Brazilian studies ${ }^{(14-17)}$ and studies from other countries in Latin America ${ }^{(18-20)}$, the USA ${ }^{(21,22)}$, Asia $(83.2 \% \text { UC })^{(23)}$, France $(64 \% \mathrm{UC})^{(24)}$ and Denmark $(54 \% \mathrm{UC})^{(25)}$. One study from North America demonstrated that UC is more common in the Hispanic population ${ }^{(26)}$. Several studies in the world have shown that even though $\mathrm{UC}$ is still the most prevalent IBD in some places, $\mathrm{CD}$ has been the most incident $\mathrm{IBD}^{(27,28)}$. In places with a higher incidence of IBD, the number of CD patients already surpasses that of UC patients ${ }^{27,29)}$. In our study, we noticed a small difference in the numbers of $\mathrm{CD}$ and $\mathrm{UC}$ patients.

The two diseases were more prevalent among females, following the trend in other countries ${ }^{(19,24,26,29,30)}$. The mean age at diagnosis in our study was 37 years. This finding follows results from Rio de Janeiro for both IBDs (36.7 years $)^{(15)}$, as well as results from São Paulo (35-36 years) $)^{(17)}$ and other countries such as Colombia (37.3 years), the Netherlands ( 34 years) $)^{(18)}$ and Asia $\left(36.3\right.$ years ${ }^{(24)}$. Our data confirmed a trend showing a younger mean age at diagnosis for CD than for UC. This finding is probably explained by the tendency of $\mathrm{CD}$ to affect patients at a younger age ${ }^{(2,3,31)}$.

The mean time between the onset of symptoms and diagnosis was 23 months. This time was longer in CD patients (28 months) than in UC patients, which aligned with findings from previous studies ${ }^{(2,14,32,33)}$. This timing reflects a noticeably delayed diagnosis compared to countries such as Peru (14.6 months) ${ }^{(18)}$, Iran (15.8 months) ${ }^{(30)}$ and other international centres, in which the time between the onset of symptoms and diagnosis is 1 to 9 months $^{(3,25,31,34,35)}$. The greater delay in the diagnosis of $\mathrm{CD}$ in relation to UC may be due to the lower frequency of alarming symptoms and a higher frequency of unspecific and insidious systemic symptoms, which, in some cases, may be confused with other aetiologies such as irritable bowel syndrome (IBS). Researchers 
have suggested that characteristics that are similar between irritable bowel syndrome and IBD have been associated with a delay in the diagnosis of Crohn's disease ${ }^{(36,37)}$.

The main clinical manifestation was weight loss, followed by diarrhoea, abdominal pain, faecal urgency, asthenia and blood in the stool. These findings are similar to results from the USA ${ }^{(34)}$. The description of fever during the onset of symptoms occurred in $38.3 \%$ of IBD patients. The extraintestinal manifestations at the beginning of the symptoms corresponded to reports from $41.6 \%$ of patients, slightly higher than findings presented in a study from Iran, in which $32.4 \%$ of IBD patients presented at least one extraintestinal manifestation at diagnosis ${ }^{(30,38)}$. The CD patients presented more weight loss, abdominal pain, asthenia, appetite loss, malnutrition, anaemia, insomnia, fever, nausea and vomiting than UC patients. The UC patients reported more blood and mucus in the stool, urgency, faecal incontinence and tenesmus. More recently, a study suggested that dyssynergic defecation is highly prevalent in IBD patients ${ }^{(39)}$.

The most common symptom described in CD patients was chronic diarrhoea ${ }^{(40)}$. Abdominal pain and weight loss were seen prior to diagnosis in 80 and $60 \%$ of the Caucasian patients, respectively ${ }^{(32,41)}$. A Chinese study showed that the main manifestations of CD were non-specific symptoms such as abdominal pain $(83.3 \%)$, diarrhoea $(46.2 \%)$, weight loss $(45.4 \%)$ and fever $(37.1 \%)^{(42)}$. These results were similar to the Caucasian population and our sample, except for diarrhoea that presented a less frequency in the Chinese population. The most common symptom in our sample was weight loss, affecting $90 \%$ of the patients. This finding could be explained by the delay in the diagnosis. The extraintestinal involvement was quite relevant in $\mathrm{CD}$ patients, being far higher than that reported by the ECCO (European Crohn's and Colitis Organization) consensus $^{(38)}$. It was noteworthy that systemic manifestations such as weight loss and asthenia showed a higher frequency than some other digestive symptoms associated with IBD.

The main clinical manifestations in UC patients observed in our study were stool blood, diarrhoea, faeces mucus, weight loss, abdominal pain and asthenia. Data from developed countries, Asian Centers and from our study are similar about the main symptoms at the onset of the clinical manifestation ${ }^{(42)}$. As reported by the second ECCO guideline for ulcerative colitis, the main symptom of $\mathrm{UC}$ is visible blood in the stool ${ }^{(7)}$. Our finding is in agreement with this statement, showing that blood in the stool was the main symptom. There is no doubt that blood in the stool is a crucial symptom for the physician to suspect ulcerative colitis even if the clinician is not specialized in IBD.

CD patients presenting ileal disease frequently have systemic manifestations, and these results were confirmed in our study. Furthermore, CD patients with small intestine involvement usually present diarrhoea without urgency. In our study, urgency and faecal incontinence were frequent manifestations in colonic $\mathrm{CD}$ patients and in UC patients since urgency and possible faecal incontinence are symptoms related to cases of colonic and rectal involvement due to the loss of rectal distensibility ${ }^{(39)}$. We noticed that colonic Crohn's disease may present symptoms similar to those of UC. A new and important finding about location in the present study was that patients with isolated colonic involvement compared to other locations presented a higher frequency of alarming symptoms such as mucus and bloody diarrhoea, urgency, faecal incontinence, tenesmus, abdominal pain, weight loss, malnutrition, anaemia, and fever. This high frequency of alarming clinical manifestations may be the reason for a shorter time to diagnosis of colonic CD than found with other disease locations.

The left-sided colitis patients reported more diarrhoea with blood and mucus in the stool, faecal urgency and abdominal pain than proctitis patients, which may explain the earlier diagnosis of left-sided colitis patients. On the other hand, patients with proctitis presented a lower frequency of manifestations, which may contribute to a delay in the diagnosis of these patients compared to patients with other UC locations.

Patients diagnosed before the age of 16 years presented the highest frequency of most symptoms. Otherwise, patients over 40 years of age generally had a lower frequency of symptoms, similar to the findings of the studies of Charpentier and Conley ${ }^{(29,32)}$. Clinical manifestations were mild in older patients compared with those in younger patients as described by Butter ${ }^{(43)}$. This difference is possibly due to a less active immune system. On the other hand, the high frequency of insomnia may be a typical symptom of patients with advancing age.

In the onset of the clinical manifestations of $\mathrm{UC}$, the presence of intestinal symptoms was described more frequently by UC patients than by CD patients. Otherwise, CD patients usually presented with more pronounced systemic symptoms. This characteristic of CD contributes to a delayed diagnosis, especially when the patient seeks care with a team not familiar with IBD.

Finally, our sample included patients who typically had an established diagnosis of IBD at follow-up. Memory biases may have occurred. In the future, prospective studies involving incidental cases may lead to clearer characterization of the onset of clinical manifestations of IBD in patients.

\section{CONCLUSION}

Ulcerative colitis presented a high frequency of intestinal symptoms, and Crohn's disease showed a high frequency of systemic manifestations. There was a long delay in diagnosis, but individuals with disease in more extensive locations and more pronounced symptoms showed a shorter delay in diagnosis. The characterization of the onset of symptoms is critical so that health professionals can suspect IBD from the onset of the disease, contributing to an earlier diagnosis.

\section{ACKNOWLEDGEMENTS}

We appreciate the support of the fellowship programme of the Universidade do Estado da Bahia and the Foundation of Research Support in the State of Bahia (FAPESB). We appreciate Vinícius Gomes Nóbrega and the staff of Hospital Geral Roberto Santos: Dr. Andrea Maia Pimentel, Dr. Jaciane Mota, Dr. Neogélia Pereira de Almeida and Dr. Valdiana Cristina Surlo.

\section{Authors' contributions}

Nóbrega VG: data collection, survey execution, statistical analysis and wrote the paper. Silva INN, Brito BS, Silva J, and Silva MCM: data collection and prepare the database. Santana GO: wrote the project, wrote and reviewed the paper. 
Nóbrega VG, Silva INN, Brito BS, Silva J, Silva MCM, Santana GO. Manifestações clínicas iniciais em pacientes com doença inflamatória intestinal. Arq Gastroenterol. 2018,55(3):290-5.

RESUMO - Contexto - O diagnóstico da doença inflamatória intestinal é frequentemente retardado pela falta de capacidade para reconhecer as suas principais manifestações clínicas. Objetivo - Nosso estudo teve como objetivo descrever as manifestações clínicas iniciais em pacientes com doença inflamatória intestinal. Métodos - Estudo transversal. Os pesquisadores obtiveram dados por entrevistas e registros médicos de pacientes com doença inflamatória intestinal em um centro de referência localizado na Bahia. Resultados - Foram incluídos 306 pacientes. O tempo entre o início dos sintomas e o diagnóstico foi de $28( \pm 48)$ meses para doença de Crohn e $19( \pm 46)$ meses para colite ulcerativa. O tempo médio desde o início dos sintomas clínicos até o diagnóstico de doença de Crohn foi de 37 meses para pacientes com localização do ileocolon, 26 meses para a localização do íleo e 18 meses para a localização do cólon. Nos doentes com colite ulcerativa, o tempo médio desde o início dos sintomas até ao diagnóstico foi de 52 meses para proctite, 12 meses para colite no lado esquerdo e 12 meses para colite extensa. As principais manifestações clínicas em pacientes com doença de Crohn foram perda de peso, dor abdominal, diarreia e astenia. Os sintomas mais relevantes da colite ulcerativa foram sangue nas fezes, urgência fecal, diarreia, muco nas fezes, perda de peso, dor abdominal e astenia. Observou-se que a perda de peso, dor abdominal e distensão, astenia, perda de apetite, anemia, insônia, febre, náusea, doença perianal, manifestação extraintestinal, afta oral, vômitos e massa abdominal foram mais frequentes na doença de Crohn. A frequência de urgência e incontinência fecal, fezes com muco e sangue, tenesmo e constipação foram maiores na colite ulcerativa. Conclusão - A colite ulcerativa apresentou alta frequência de sintomas intestinais e a doença de Crohn mostrou alta frequência de manifestações sistêmicas. Houve um grande atraso no diagnóstico, mas indivíduos com doença mais extensa e sintomas mais exuberantes mostraram um atraso menor.

DESCRITORES - Doenças inflamatórias intestinais. Doença de Crohn. Colite ulcerativa.

\section{REFERENCES}

1. Baumgart DC, Sandborn WJ. Inflammatory bowel disease: clinical aspects and established and evolving therapies. Lancet. 2007;369:1641-57.

2. Stylianou E. Recent Advances in the Etiopathogenesis of inflammatory bowel disease: the role of omics. Mol Diagn Ther. 2018;22:11-23.

3. Rogler G, Biedermann L, Scharl M, et al. New insights into the pathophysiology of inflammatory bowel disease: microbiota, epigenetics and common signalling pathways. Swiss Med Wkly. 2018;148:14599.

4. Gomollón F, Dignass A, Annese V, Tilg H, Van Assche G, Lindsay JO, et al. 3rd European evidence-based consensus on the diagnosis and management of Crohn's disease 2016: Part 1: diagnosis and medical management. J Crohns Colitis. 2017;11:3-25.

5. Remo Panaccione, MD, FRCPC. Mechanisms of inflammatory bowel disease Gastroenterol Hepatol (NY). 2013;9:529-32.

6. Sawczenko A, Sandhu BK. Presenting features of inflammatory bowel disease in Great Britain and Ireland. Arch Dis Child. 2003;88:995-1000

7. Dignass A, Eliakim R, Magro F, Maaser C, Chowers Y, Geboes K, et al. Second European evidence-based consensus on the diagnosis and management of ulcerative colitis part 1: definitions and diagnosis. J Crohns Colitis. 2012; 6:965-90.

8. Hohmann EL, Ananthakrishnan AN, Deshpande V. Case Records of the Massachusetts General Hospital. Case 25-2014. A 37-year-old man with ulcerative colitis and bloody diarrhea. N Engl J Med. 2014;371:668-75.

9. da Silva BC, Lyra AC, Mendes CM, Ribeiro CP, Lisboa SR, de Souza MT, et al. The demographic and clinical characteristics of ulcerative colitis in a Northeast Brazilian population. Biomed Res Int. 2015, 2015:1-8.

10. Knowles SR. Quality of life in inflammatory bowel disease: a systematic review and meta-analyses. Inflamm Bowel Dis. 2018; 24:966-76.

11. Eluri S, Cross RK, Martin C, Weinfurt KP, Flynn KE, Long MD, et al. Inflammatory bowel diseases can adversely impact domains of sexual function such as satisfaction with sex life. Dig Dis Sci. 2018;63:1-11.

12. Lee JW. Depressive symptoms and quality of life in the patients of inflammatory bowel disease. Gut Liver. 2017;11:449-50

13. Ng SC, Shi HY, Hamidi N, Underwood FE, Tang W, Benchimol EI, et al. Worldwide incidence and prevalence of inflammatory bowel disease in the $21 \mathrm{st}$ century: a systematic review of population-based studies. Lancet. 2018;390 2769-78.

14. Gaburri PD, Chebli JM, de Castro LE, Ferreira JO, Lopes MH, Ribeiro AM, et al. [Epidemiology, clinical features and clinical course of Crohn's disease: a study of 60 cases]. [Article in Portuguese]. Arq Gastroenterol. 1998;35:240-6.

15. Souza MHLP, Troncon LEA, Rodrigues CM, Viana CF, Onofre PH, Monteiro RA, et al. Trends in the occurrence (1980-1999) and clinical features of Crohn's disease and ulcerative colitis in a university hospital in Southeastern Brazil. Arq. Gastroenterol. 2002;39:98-105.

16. Souza MM De, Belasco AGS, Aguilar-Nascimento JE De. Perfil epidemiológico dos pacientes portadores de doença inflamatória intestinal do estado de Mato Grosso. Ver Bras Coloproctol. 2008;28:324-8.
17. Victoria CR, Sassak LY, Nunes HR. Incidence and prevalence rates of inflammatory bowel diseases, in midwestern of São Paulo State, Brazil. Arq Gastroenterol 2009,46:20-5.

18. Paredes Méndez J, Otoya Moreno G, Mestanza Rivas Plata AL, Lazo Molina L, Acuña Ordoñez K, Arenas Gamio JL, et al. [Epidemiological and clinica characteristics of inflammatory bowel disease in a tertiary referral hospital in Lima-Peru]. [Article in Spanish]. Rev Gastroenterol Perú. 2016;36:209-18.

19. Mendoza Ladd A, Jia Y, Yu C, Elhanafi S, Dwivedi A, Liu J, et al. Demographic and clinical characteristics of a predominantly hispanic population with inflammatory bowel disease on the US-Mexico border. South Med J. 2016;109:792.

20. Simian D, Fluxá D, Flores L, Lubascher J, Ibáñez P, Figueroa C, et al. Inflammatory bowel disease: a descriptive study of 716 local Chilean patients. World J Gastroenterol. 2016;22:5267-75.

21. Betteridge JD, Armbruster SP, Maydonovitch C, Veerappan GR. Inflammatory bowel disease prevalence by age, gender, race, and geographic location in the U.S military health care population. Inflamm Bowel Dis. 2013;19:1421-7.

22. Hou JK, Feagins LA, Waljee AK. Characteristics and behavior of Elderly-342 onset inflammatory bowel disease: a multi-center US study. Inflam Bowel Dis. 2016;22:2200-5.

23. Subasinghe D, Nawarathna NMM, Samarasekera DN. Disease characteristics of inflammatory bowel disease (IBD). J Gastrointest Surg. 2011;15:1562-7.

24. Basaranoglu M, Sayilir A, Demirbag AE, Mathew S, Ala A, Senturk H, et al. Seasonal clustering in inflammatory bowel disease: a single centre experience. Expert Rev Gastroenterol Hepatol. 2015;9:877-81.

25. Burisch J. Crohn's disease and ulcerative colitis. Occurrence, course and prognosis during the first year of disease in a European population-based inception cohort Dan Med J. 2014;61:B4778.

26. Avalos DJ, Mendoza-Ladd A, Zuckerman MJ, Bashashati M, Alvarado A, Dwivedi A, Damas OM, et al. Hispanic Americans and non-Hispanic white Americans have a similar inflammatory bowel disease phenotype: a systematic review with meta-analysis. Dig Dis Sci. 2018;68:1-14.

27. Anderson AJ, Click B, Ramos-Rivers C, Babichenko D, Koutroubakis IE, Hartman DJ, et al. Development of an inflammatory bowel disease research registry derived from observational electronic health record data for comprehensive clinical phenotyping. Dig Dis Sci. 2016;61:3236-45

28. Burisch J, Munkholm P. The epidemiology of inflammatory bowel disease. Scand J Gastroenterol. 2015;50:942-51.

29. Conley S, Proctor DD, Jeon S, Sandler RS, Redeker NS. Symptom clusters in adults with inflammatory bowel disease. Res Nurs Health. 2017;4:424-34.

30. Aghazadeh R, Zali MR, Bahari A, Amin K, Ghahghaie F, Firouzi F. Inflammatory bowel disease in Iran: a review of 457 cases. J Gastroenterol Hepatol. 2005;20:1691-5.

31. Zaharie R, Tantau A, Zaharie F, Tantau M, Gheorghe L, Gheorghe C, et al Diagnostic delay in Romanian patients with inflammatory bowel disease: risk factors and impact on the disease course and need for surgery. J Crohns Colitis 2016;10:306-14 
32. Charpentier C, Salleron J, Savoye G, Fumery M, Merle V, Laberenne JE, et al. Natural history of elderly-onset inflammatory bowel disease: a population-based cohort study. Gut. 2014;63:423-32.

33. Solberg IC, Vatn MH, Høie O, Stray N, Sauar J, Jahnsen J, et al. Clinical course in Crohn's disease: results of a Norwegian population-based ten-year follow-up study. Clin Gastroenterol Hepatol. 2007;5:1430-8.

34. Heikenen JB, Werlin SL, Brown CW, Balint JP. Presenting symptoms and diagnostic lag in children with inflammatory bowel disease. Inflamm Bowel Dis. 1999;5:158-60.

35. Schoepfer AM, Dehlavi MA, Fournier N, Safroneeva E, Straumann A, Pittet V, et al. Diagnostic delay in Crohn's disease is associated with a complicated disease course and increased operation rate. Am J Gastroenterol. 2013;108:1744-53.

36. Andresen V, Layer P. Irritable bowel syndrome - a disease. Dtsch Med Wochenschr. 2018;143:411-9.

37. Hoekman DR, Zeevenhooven J, D'Haens GR, Benninga MA. The prevalence of irritable bowel syndrome-type symptoms in inflammatory bowel disease patients in remission. Eur J Gastroenterol Hepatol. 2017;29:1086-90.
38. Harbord M, Annese V, Vavricka SR, Allez M, Barreiro-de Acosta M, Boberg $\mathrm{KM}$, et al. The first European evidence-based consensus on extra-intestinal manifestations in inflammatory bowel disease. J Crohns Colitis. 2016;10:239-54.

39. Rezaie A, Gu P, Kaplan GG, Pimentel M, Al-Darmaki AK, et al. Dyssynergic defecation in inflammatory bowel disease: a systematic review and meta-analysis. Inflamm Bowel Dis. 2018;24:1065-73.

40. Sands BE. From symptom to diagnosis: clinical distinctions among various forms of intestinal inflammation. Gastroenterol. 2004;126:1518-32.

41. Chinese IBD Working Group. Retrospective analysis of 515 cases of Crohn's disease hospitalization in China: nationwide study from 1990 to 2003. J Gastroenterol Hepatol. 2006;21:1009-15.

42. Wang YF, Zhang H, Ouyang Q. Clinical manifestations of inflammatory bowel disease: East and West differences. J Dig Dis. 2007;8:121-7.

43. Butter M Weiler S, Biedermann L, Scharl M, Rogler G, Bischoff-Ferrari HA, Misselwitz B. Clinical manifestations, pathophysiology, treatment and outcome of inflammatory bowel diseases in older people. Maturitas. 2018;110:71-8. 